\title{
Pengaruh Ekstrak Biji Ketumbar (Coriandrum Sativum) Terhadap Kadar Trigliserida Dan Gambaran Histologi Hati Tikus (Rattus Novergicus) Yang Diinduksi Oleh Pakan Tinggi Lemak
}

\section{The Effect Of Coriander Seed Extract (Coriandrum Sativum L.) On Triglycerides And Histological Of High Fat Diet-Induced Hyperlipidemia In Rats (Rattus Novergicus)}

\author{
Liah Kodariah $^{1 *}$, Aziz Ansori Wahid ${ }^{1}$ \\ ${ }^{1}$ Program Studi DIII Analis Kesehatan, Fakultas Farmasi dan Teknologi Laboratorium Medik, \\ Institut Kesehatan Rajawali, Bandung \\ *E-mail: $\underline{\text { liahkdrh@gmail.com }}$
}

\begin{abstract}
Abstrak
Hiperlipidemia merupakan salah satu penyebab penyakit jantung koroner yang ditandai dengan adanya penumpukan lemak yang disebabkan oleh kadar trigliserida tinggi. Hiperlipidemia dapat mengakibatkan perlemakan hati (fatty-liver) sehingga hepatosit mengalami kerusakan dan peningkatan aktivitas enzim transaminase. Hati memiliki peran penting untuk metabolisme lipid karena lipid diangkut di dalam darah sebagai lipoprotein yang dibentuk di dalam hati. Tujuan penelitian ini adalah untuk mempelajari pengaruh ekstrak biji ketumbar terhadap kadar trigliserida serum darah dan gambaran histologi hati tikus putih yang diinduksi pakan tinggi lemak. Penelitian menggunakan metode eksperimen, sampel sebanyak 24 ekor tikus putih galur Wistar dikelompokkan kedalam 6 kelompok, yaitu: K1 (tikus diberi pakan normal dan diberi akuades), K2 (tikus hanya diberi pakan tinggi lemak), K3 (tikus diberi pakan tinggi lemak dan simvastatin dosis $0,18 \mathrm{mg} / \mathrm{kg} \mathrm{BB} / \mathrm{hari}$ ), $\mathrm{K} 4$, K5, dan K6 (tikus diberi pakan diet tinggi lemak dan diberikan ekstrak biji ketumbar dengan dosis masingmasing 5,4 mg/kg BB/hari, 10,8 mg/kg BB/hari, dan 21,6 mg/kg BB/hari). Hasil penelitian menunjukkan adanya penurunan kadar trigliserida serum darah tikus sebelum dan setelah diberikan ekstrak biji ketumbar. Pada gambaran histologi K1, K3, K4, K5, dan K6 didapatkan gambaran histologi hati yang normal, sedangkan pada K2 ditemukan sel kariolisis (nekrosis). Berdasarkan hasil penelitian dapat disimpulkan bahwa ekstrak biji ketumbar berpengaruh terhadap penurunan kadar trigliserida serum darah tikus dan adanya perubahan histologi hati pada kelompok tikus yang diberikan ekstrak biji ketumbar dengan kelompok yang tidak diterapi.
\end{abstract}

Kata kunci: biji ketumbar, trigliserida, histologi, hati, hiperlipidemia.

\begin{abstract}
Hyperlipidemia is one of the causes of coronary heart disease marked by the accumulation of fat caused by high triglyceride levels. Hyperlipidemia can cause fatty liver so that hepatocytes experience damage and increase the activity of the transaminase enzyme. The liver has an important role in lipid metabolism because lipids are transported in the blood as lipoproteins formed in the liver. The purpose of this study is to investigate the effect of coriander seed extract on blood serum triglyceride levels and the histological picture of white rat liver induced by high-fat feed. The study used an experimental method in which a sample of 24 white rats were grouped into 6 groups, $K 1$ (rats were given normal feed and given aqua dest), K2 (rats were only given high-fat feed), K3 (rats were given high-fat feed and simvastatin dose $0.18 \mathrm{mg} / \mathrm{kg} /$ day), while $\mathrm{K} 4$, K5, and $\mathrm{K} 6$ (rats were fed a diet high in fat and given coriander seed extract at a dose of $5.4 \mathrm{mg} / \mathrm{kg} /$ day, $10.8 \mathrm{mg} / \mathrm{kg} / \mathrm{day}$, and 21.6 $\mathrm{mg} / \mathrm{kg} /$ day respectively). The results showed a decrease in rat serum triglyceride level before and after coriander seed extract was given. In the histological features of $K 1, K 3, K 4, K 5$, and K6, a normal histological picture of the liver was found, while karyolysis cells (necrosis) were observed in K2 group. Based on the results of the study, the coriander seed extract might affect the reduction in rat serum triglyceride level as well as the histological changes of liver in rats treated with coriander seed extract as compared to the untreated group.
\end{abstract}

Keywords: coriander seed, triglyceride, histology, liver, hyperlipidemia 


\section{Pendahuluan}

Hiperlipidemia adalah suatu keadaan patologis akibat kelainan metabolisme lemak darah yang ditandai dengan meningginya kadar kolesterol darah (hiperkolesterolemia), trigliserida (hipertrigliserida), atau kombinasi keduanya. Hiperlipidemia umumnya tidak menunjukkan gejala klinis yang spesifik, namun hiperlipidemia berat dan kronis pada beberapa kasus ditandai dengan munculnya xanthoma, yaitu deposit lemak berupa benjolan atau nodul berwarna kekuningan pada kulit di daerah mata ${ }^{1}$.

Berdasarkan mekanisme terjadinya, kejadian hiperlipidemia dapat terjadi dengan 3 mekanisme, yaitu kelainan pada enzim lipoprotein dan Apolipoprotein C-II (ApoC-II), kelainan dalam eliminasi low density lipoprotein (LDL), dan kelainan Apolipoprotein E (ApoE) dan pembuangan sisa. Penyebab hiperlipidemia dapat dikelompokan menjadi dua jenis yaitu hiperlipidemia primer dan hiperlipidemia sekunder ${ }^{1}$. Hiperlipidemia primer terjadi akibat kelainan genetik yang mengkode enzim, apoprotein, atau reseptor yang terlibat dalam metabolisme lipid. Hiperlipidemia sekunder terjadi akibat gangguan sistemik. Penyebab utama hiperlipidemia sekunder adalah obesitas, asupan alkohol berlebihan, diabetes melitus, hipotiroidisme, dan sindrom nefrotik.

Hiperlipidemia dapat mengakibatkan perlemakan hati (fatty-liver) sehingga hepatosit mengalami kerusakan dan peningkatan aktivitas enzim-enzim trans-aminase yang merupakan penanda gangguan fungsi hepar. Steatosis hati termasuk dalam kelompok non-alcoholic fatty liver disease (NAFLD). NAFLD ini terjadi karena adanya akumulasi asam lemak dalam berbagai bentuk, terutama trigliserida, akibat pergeseran metabolisme asam lemak yang lebih berperan dalam mendukung lipogenesis daripada lipolisis $^{2}$.

Trigliserida berperan dalam pengangkutan dan penyimpanan lipid serta merupakan simpanan lipid utama pada manusia. Peningkatan trigliserida dapat disebabkan oleh terjadinya peningkatan influks asam lemak ke dalam hati, penurunan oksidasi asam lemak atau peningkatan sintesis asam lemak di hati. Pada penyakit perlemakan hati non-alkoholik, terjadinya peningkatan trigliserida kemungkinan disebabkan oleh penurunan oksidasi asam lemak. Trigliserida selanjutnya akan didistribusi ke seluruh tubuh. Pada peningkatan trigliserida di hati akan terjadi pula peningkatan kadar trigliserida darah ${ }^{3}$. Selain itu, peningkatan trigliserida ini terjadi akibat peningkatan proses lipogenesis de-novo yaitu proses glukosa yang tidak terpakai menjadi sumber energi dikonversi menjadi asam lemak bebas selanjutnya disimpan dalam bentuk trigliserida di hati. Peningkatan kadar triglserida juga meningkatkan risiko terjadinya perlemakan hati non-alkoholik sebanyak 13 kali lipat daripada yang memiliki kadar trigliserida normal. ${ }^{3}$

Hati merupakan sebuah organ besar yang mengandung sedikit jaringan ikat. Hati memiliki peran penting untuk metabolisme lipid, karena lipid diangkut di dalam darah sebagai lipoprotein, dan lipoprotein ini dibentuk di dalam hati. Hati juga mensintesis kolesterol, mengeluarkan pigmen empedu dari uraian hemoglobin sel darah merah yang rusak, dan menghasilkan urea. Sintesis lipid ini terjadi didalam hati bagian retikulum endoplasma kasar dan halus ${ }^{44}$.

Berdasarkan data Badan Penelitian dan Pengembangan Kesehatan ${ }^{5}$ tahun 2013, kolesterol total abnormal pada penduduk Indonesia usia $\geq 15$ tahun sebesar 35,9\%, trigliserida borderline tinggi sebesar $13 \%$, dan terdapat $15,9 \%$ penduduk usia $\geq 15$ tahun dengan kadar LDL tinggi atau sangat tinggi. Penatalaksanaan hiperlipidemia dilakukan melalui modifikasi perilaku/gaya hidup antara lain dengan menerapkan pola makan (diet) rendah lemak dan melakukan aktivitas fisik (olah raga) yang cukup, namun apabila penanganan non medikamentosa dianggap tidak memadai, pada beberapa kasus hiperlipidemia diperlukan pemberian obat antidislipidemia atau anti hiperlipidemia.

Ketumbar mengandung minyak atsiri dalam jumlah tinggi. Tanaman ini merupakan sumber lipid potensial karena kaya akan asam petroselinic dan minyak atsiri (tinggi linalool) yang diisolasi dari biji. Hasil skrining fitokimia ekstrak biji ketumbar menunjukan adanya senyawa alkaloid, saponin, tannin, flavonoid, fenolik, triterpenoid, dan glikosida ${ }^{6}$.

Pengendalian kadar kolesterol pada darah dapat dilakukan dengan melakukan diet, olahraga, maupun dengan menggunakan obatobatan hipolipidemia yang dapat menurunkan kadar kolesterol pada darah atau bersifat 
hipokolesterolemik. Pengaturan diet yang dikonsumsi merupakan cara yang sederhana, murah, dan aman untuk pengendalian kadar kolesterol pada darah. Diet yang baik untuk penderita hiperlipidemia adalah makanan yang mengandung karbohidrat termasuk serat pangan, rendah sukrosa, dan glukosa, rendah kolesterol, dan asam-asam lemak jenuh, serta mengandung protein yang memadai sehingga dapat menurunkan kadar kolesterol. Bahan makanan yang memiliki potensi menurunkan kadar kolesterol darah adalah buah-buahan terutama yang mengandung vitamin $\mathrm{C}$ dan memiliki serat. Penggunaan obat-obat tradisional yang berasal dari alam sudah banyak dilakukan masyarakat Indonesia. Salah satu tanaman obat yang mulai diteliti saat ini adalah biji ketumbar.

Hiperlipidemia meningkatkan risiko pembentukan produk oksidasi lipid, yang menumpuk di ruang sub-endotel pembuluh darah dan tulang. Ketumbar yang diberikan dengan dosis $1 \mathrm{~g} / \mathrm{kg}$ BB mencit yang diinduksi hiperlipidemia dapat mengurangi penyerapan dan meningkatkan pemecahan lemak jika dibandingkan dengan obat herbal yang tersedia secara komersial untuk hipolipidemia. Oleh sebab itu, ketumbar dapat digunakan sebagai herbal preventif dan kuratif terhadap hiperlipidemia ${ }^{7}$.

Penelitian lain menyebutkan bahwa pemberian biji ketumbar pada tikus yang diberi pakan diet tinggi lemak menunjukkan efek hipolipidemik yang signifikan. Biji ketumbar bermanfaat melindungi hati dari stres oksidatif yang disebabkan oleh carbon-tetrachloride $\left(\mathrm{CCl}_{4}\right)^{8}$. Senyawa bioaktif yang sangat protektif untuk melindungi hati adalah senyawa alkaloid, flavonoid dan fenolik memiliki aktivitas biologis yang dapat merangsang enzim pencernaan dan peningkatan fungsi hati ${ }^{9}$.

Hiperlipidemia dapat menyebabkan penumpukan lemak di hati (perlemakan hati) yang mengakibatkan terganggunya fungsi hati. Pengobatan yang digunakan untuk mengurangi perlemakan hati biasanya obat-obatan sintesis seperti statin. Tetapi jika statin digunakan dalam jangka waktu yang lama, akan memberikan efek samping seperti miopati dan gagal ginjal, sehingga diperlukannya pengobatan alternatif untuk mengurangi perlemakan di hati ${ }^{10}$. Salah satu pengobatan alternatif yang mudah dicari dan aman yaitu biji ketumbar yang memiliki efek farmakologis seperti aktivitas antioksidan. Penelitian ini bertujuan untuk mempelajari pengaruh ekstrak biji ketumbar (Coriandrum sativum) terhadap kadar trigliserida serum darah tikus dan untuk melihat gambaran histologi hati tikus putih (Rattus norvegicus) yang diinduksi hiperlipidemia melalui diet tinggi lemak.

\section{Metode}

Penelitian ini merupakan penelitian eksperimental yang dilakukan di Laboratorium Farmakologi, Fakultas Kedokteran Universitas Padjajaran. Waktu penelitian dilakukan pada bulan Februari - April 2019.

Terdapat 6 kelompok perlakuan, yaitu kelompok kontrol negatif (K1) adalah tikus yang normal, kelompok hiperlipidemia (K2) adalah tikus yang diberi pakan diet tinggi lemak, kelompok simvastatin (K3) adalah tikus yang diberi pakan diet tinggi lemak dan diberikan simvastatin $0,18 \mathrm{mg} / \mathrm{kg} \mathrm{BB} /$ hari, kelompok dosis I ekstrak biji ketumbar (K4) adalah tikus yang diberi pakan diet tinggi lemak dan diberikan ekstrak biji ketumbar dengan dosis $5,4 \mathrm{mg} / \mathrm{kg}$ $\mathrm{BB} /$ hari, kelompok dosis II ekstrak biji ketumbar (K5) tikus yang diberi pakan diet tinggi lemak dan diberikan ekstrak biji ketumbar dengan dosis $10,8 \mathrm{mg} / \mathrm{kg} \mathrm{BB} /$ hari, dan kelompok dosis III ekstrak biji ketumbar (K6) adalah tikus yang diberi pakan diet tinggi lemak dan diberikan ekstrak biji ketumbar dengan dosis 21,6 mg/kg $\mathrm{BB} /$ hari. Hewan yang digunakan pada penelitian ini adalah tikus putih jantan (Rattus novergicus) yang berumur 8-12 minggu dengan berat 200250 g. Besar sampel ditentukan sesuai dengan rumus Federer $^{1}$, sehingga jumlah sampel pada setiap perlakuan adalah 4 ekor tikus dan jumlah seluruh tikus yang digunakan pada penelitian ini adalah 24 ekor.

Pada penelitian ini, kriteria inklusi adalah tikus putih jantan berumur 8-12 minggu, berat 200-250 g, dalam kondisi sehat, gerakangerakan makan dan minum dalam keadaan tenang, tidak ada luka dan cacat. Sedangkan kriteria eksklusi adalah tikus putih dalam kondisi sakit, mati, dan stres.

\section{Pembuatan Ekstrak Biji Ketumbar (Coriandrum sativum)}

Pembuatan ekstrak dilakukan dengan cara berikut: biji ketumbar yang tua dan kering sebanyak $1000 \mathrm{~g}$ dihancurkan dengan mortir 
sampai halus. Proses pengecilan ukuran ini bertujuan agar kelenjar minyak dapat terbuka sebanyak mungkin sehingga pada proses ekstraksi laju penguapan minyak atsiri menjadi cukup cepat. Setelah diperoleh biji ketumbar yang halus, bahan dibungkus dengan kertas saring dan dilakukan proses ekstraksi. Ekstraksi dilakukan dengan menggunakan pelarut $\mathrm{N}$ heksana sebanyak $2500 \mathrm{~mL}$, kemudian disaring dan dipekatkan dengan rotary evaporator pada suhu $40^{\circ} \mathrm{C}^{12}$.

Pengujian fitokimia dilakukan pada simplisia kering dan ekstrak yang diperoleh. Pengujian fitokimia bertujuan untuk mengetahui secara kualitatif kandungan senyawa metabolit sekunder yang terdapat dalam sampel. Sampel tumbuhan dikeringkan dengan menggunakan oven bersuhu $40^{\circ} \mathrm{C}$ hingga kadar airnya kurang $10 \%$, setelah kering sampel dihaluskan kemudian diuji fitokimia ${ }^{13}$.

\section{Pembuatan Makanan Diet Tinggi Lemak}

Pakan diberikan secara ad libitum (secara terus menerus) selama 2 minggu. Prosedur pembuatan makanan diet tinggi lemak tikus putih jantan untuk 1 minggu adalah sebanyak 8 $\mathrm{kg}$ pelet standar, $2,5 \mathrm{~kg}$ terigu, $3 / 4 \mathrm{~kg}$ minyak kelapa sawit dicampurkan dan diaduk sampai merata. Kemudian ditambahkan 15 butir telur bebek yang direbus selama $1 / 2$ jam, diambil bagian kuning telurnya saja. Kemudian ditambahkan $1 \mathrm{~kg}$ lemak kambing dan direbus sampai lembek dan cair. Kemudian campurkan telur bebek dengan pelet, terigu, minyak kelapa sawit, dan minyak babi sampai merata. Tambahkan rebusan lemak kambing ke dalam campuran sebelumnya sampai merata, jika perlu ditambahkan sedikit air panas ${ }^{14}$.

\section{Penetapan Kadar Trigliserida}

Pengukuran kadar trigliserida dilakukan dengan metode kolorimetri enzimatik menggunakan gliserol 3-fosfat oksidase fenol aminophenazone (GPO-PAP). Trigliserida dihidrolisis secara enzimatis dengan lipase khusus menjadi gliserol dan asam bebas sehingga membentuk kompleks warna. Indikator warna pada metode ini adalah quinoneimine yang terbentuk dari reaksi 4-aminoantyprine dan 4-chlorophenol dengan hidrogen peroksida yang dikatalisis oleh enzim peroksida. Kadar quinoneimine setara dengan kadar trigliserida yang diukur menggunakan fotometer Dirui DR$7000 \mathrm{D}$ dengan panjang gelombang $546 \mathrm{~nm}$.

\section{Pengukuran Kadar Trigliserida}

Pengukuran kadar trigliserida dilakukan dengan menyiapkan 3 tabung serologi dan pipet reagen trigliserida (GPO-PAP) sebanyak 1000 $\mu \mathrm{L}$ kedalam masing- masing tabung. Selanjutnya tambahkan $10 \mu \mathrm{L}$ sampel pada tabung $1,10 \mu \mathrm{L}$ akuades pada tabung 2 dan $10 \mu \mathrm{L}$ larutan standar pada tabung 3. Kemudian masing-masing tabung dihomogenkan dan diinkubasi selama 10 menit pada suhu $20-25^{\circ} \mathrm{C}$ selama 5 menit pada suhu $37^{\circ} \mathrm{C}$. Kemudian dibaca pada alat fotometer dengan panjang gelombang $546 \mathrm{~nm}^{15}$. Perhitungan dilakukan dengan rumus :

$$
\begin{aligned}
& \text { Konsentrasi trigliserida } \quad(\mathrm{mg} / \mathrm{dL})= \\
& \frac{\text { absorbansi sampel }}{\text { absorbansi standar }} \times \text { konsentrasi standar }
\end{aligned}
$$

\section{Pembuatan Sediaan Histologi}

Prosedur pembuatan sediaan histologi yaitu tikus dibius terlebih dahulu hingga mati. Pembedahan dilakukan pada tikus untuk pengambilan organ hati yang akan dibuat menjadi preparat. Selanjutnya masukkan organ hati kedalam larutan fiksatif yaitu formaldehid $10 \%$ selama 12 jam dan potong jaringan hati tersebut dengan ukuran $1,5 \times 1 \times 0,5$ dan masukkan kedalam kaset yang telah diberi label lalu dilakukan proses dehidrasi menggunakan larutan alkohol mulai dari $70 \%, 80 \%, 90 \%$, dan $100 \%$. Kemudian proses penjernihan dilakukan menggunakan xilol dan embedding. Blok parafin dipotong dengan mikrotom untuk membuat preparat sehingga diperoleh pita-pita preparat. Kemudian diletakkan pada objek gelas yang telah diberikan perekat menggunakan albumin, lalu ditetesi akuades secukupnya dan proses staining dilakukan dengan pewarnaan Hematoksilin-Eosin ${ }^{16}$.

\section{Analisa Data}

Kadar rata-rata trigliserida serum tikus putih pada masing-masing kelompok kemudian diolah dengan uji statistik repeated ANOVA untuk menguji perbedaan dari berbagai hasil pengukuran yang dilakukan berulang-ulang pada 3 sampel atau lebih yang saling berpasangan. 
Tabel 1. Kadar Trigliserida Serum Darah Tikus

\begin{tabular}{cccccc}
\hline \multicolumn{1}{c}{ Nilai Trigliserida (mg/dL) } \\
\hline & N & $\begin{array}{c}\text { H-8 } \\
(\text { mean } \pm \text { SD) }\end{array}$ & $\begin{array}{c}\text { H-29 } \\
(\text { mean } \pm \text { SD) }\end{array}$ & $\begin{array}{c}\text { H-37 } \\
\text { (mean } \pm \text { SD) }\end{array}$ & $\begin{array}{c}\text { Presentase Perubahan } \\
\text { Kadar Trigliserida } \\
(\text { H8 }- \text { H37) }\end{array}$ \\
\hline K1 & 4 & $94,50 \pm 15,155$ & $122,25 \pm 21,407$ & $116,75 \pm 17,896$ & $-4 \%$ \\
\hline K2 & 4 & $84,75 \pm 38,065$ & $202,50 \pm 23,742$ & $207,50 \pm 23,473$ & $2 \%$ \\
\hline K3 & 4 & $83,75 \pm 21,823$ & $190,25 \pm 20,998$ & $128,50 \pm 8,583$ & $-33 \%$ \\
\hline K4 & 4 & $58,00 \pm 12,111$ & $205,00 \pm 21,954$ & $134,50 \pm 7,326$ & $-35 \%$ \\
\hline K5 & 4 & $109,25 \pm 26,349$ & $222,00 \pm 15,341$ & $123,25 \pm 7,932$ & $-44 \%$ \\
\hline K6 & 4 & $102,75 \pm 40,186$ & $221,75 \pm 27,035$ & $96,50 \pm 33,907$ & $-57 \%$ \\
\hline Mean & $88,83 \pm 29,764$ & $193,96 \pm 39,766$ & $134,50 \pm 39,362$ & $-31 \%$ \\
\hline
\end{tabular}

\section{Hasil}

\section{Hasil Ekstraksi Biji Ketumbar}

Pada proses ekstraksi dengan metode maserasi dari $1000 \mathrm{~g}$ biji ketumbar dengan larutan N-heksana $2500 \mathrm{~mL}$ diperoleh ekstrak kental sebanyak 26,69 g sehingga randemen yang diperoleh itu adalah 2,67\%. Ekstrak kental kemudian diambil sebanyak $12,32 \mathrm{~g}$, kemudian selama 3 hari dilakukan 2 kali proses penyaringan dan dipekatkan dengan rotary evaporator pada suhu $40^{\circ} \mathrm{C}$ untuk uji fitokimia. Uji fitokimia ini dilakukan untuk mengetahui senyawa kimia yang ada di dalam ekstrak biji ketumbar. Senyawa yang diidentifikasi yaitu flavonoid, saponin, tannin, alkaloid dan fenolik.

\section{Hasil Pengukuran Kadar Trigliserida}

Kadar rata-rata trigliserida serum tikus putih pada masing-masing kelompok (Tabel 1). Rata-rata nilai trigliserida serum tikus semua kelompok perlakuan pada hari ke-8 atau setelah proses adaptasi sebesar 88,83 $\pm 29,764$ mg/dLyang menunjukan kadar yang normal. Pada hari ke-23, setelah diberikan pakan diet tinggi lemak selama 3 minggu secara ad libitum, kadar trigliserida meningkat, pada K2 diperoleh $202,50 \pm 23,742 \mathrm{mg} / \mathrm{dL}$, K3 yaitu 190,25 \pm $20,998 \mathrm{mg} / \mathrm{dL}, \mathrm{K} 4$ yaitu 205,00 $\pm 21,954 \mathrm{mg} / \mathrm{dL}$, $\mathrm{K} 5$ yaitu $222,00 \pm 15,341 \mathrm{mg} / \mathrm{dL}, \mathrm{K} 6$ yaitu
$221,75 \pm 27,035 \mathrm{mg} / \mathrm{dL}$, sedangkan $\mathrm{K} 1$ yang tidak diberikan pakan diet tinggi lemak nilai trigliseridanya menunjukkan nilai yang normal yaitu $122,25 \pm 21,407 \mathrm{mg} / \mathrm{dL}$. Sedangkan pada hari ke-31 terjadi penurunan pada masingmasing kelompok tersebut yaitu pada K3 menjadi $128,50 \pm 8,583 \mathrm{mg} / \mathrm{dL}, \mathrm{K} 4$ menjadi $134,50 \pm 7,326 \mathrm{mg} / \mathrm{dL}$, K5 menjadi 123,25 \pm 7,932 mg/dL dan K6 menjadi 96,50 $\pm 33,907$ $\mathrm{mg} / \mathrm{dL}$.

\section{Analisis Data Pengukuran Kadar Trigliserida}

Perlu dilakukan uji normalitas dan uji homogenitas terhadap data sebelum melakukan analisis repeated ANOVA. Uji saphiro-wilk ( $\mathrm{n}=$ $<50$ ) merupakan salah satu uji normalitas yang dilakukan jika jumlah sampel yang digunakan kurang dari 50, pada uji ini didapatkan hasil bahwa data kadar trigliserida serum pada hari ke-8 atau pada proses adaptasi mempunyai nilai signifikansi yaitu 0,352 pada hari ke-23 setelah diberikan pakan diet tinggi lemak data kadar trigliserida memiliki nilai signifikansi yaitu 0,043 dan pada hari ke 31 setelah diberikan perlakuan data kadar trigliserida mempunyai nilai signifikansi yaitu 0,004 .

Dari hasil tranformasi data yang dilakukan pada hari ke-23 diperoleh hasil yaitu 0,691 dan hari ke-31 diperoleh hasil yaitu 0,189. Hasil tersebut menyatakan bahwa hasil 
transformasi data terdistribusi normal karena nilai asymp. Sig. $>0,05$. Sehingga dapat dilanjutkan analisis data dengan repeated ANOVA.

Pada analisis data dengan menggunakan repeated ANOVA dilihat dari nilai Mauchly's Test of Sphericity, test tersebut menunjukan nilai 0.969 hal ini menunjukan nilai tersebut $>0,05$ yang dapat disimpulkan bahwa nilai tersebut memenuhi asumsi kesamaan varians atau homogen. Dan pada Sphericity Assumed diperoleh nilai sig. yaitu 0.000 hal tersebut menunjukan nilai $<0.05$ dan dapat disimpulkan terdapat pengaruh ekstrak biji ketumbar terhadap kadar trigliserida tikus putih.

Analisis uji post hoc Tukey untuk menunjukkan perbedaan siginifikan antar kelompok, jika nilai sig. $<0.05$ menunjukan perbedaan bermakna sedangkan jika nilai
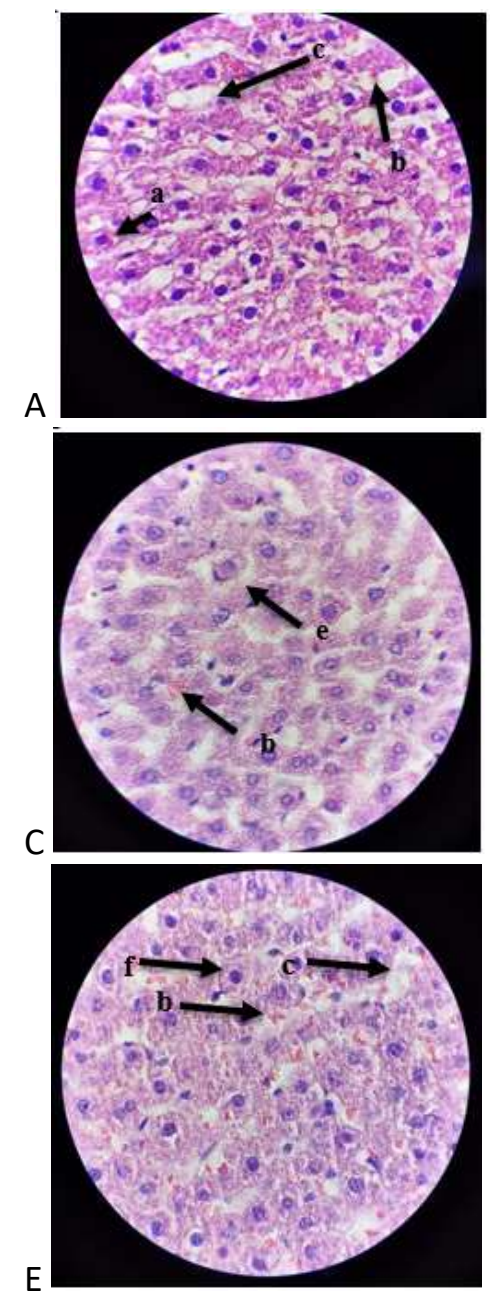

Gambar 2. Gambaran Histologi Hati Tikus Putih (Rattus novergicus).

Keterangan : A. K1; B. K2; C. K3; D. K4; E. K5; dan F. K6. a. sel hepatosit; b. sel eritrosit; c. ruang interstitial; d. sel kariolisis; e. sel kupfer; f. hepatosit

sig. $>0.05$ maka terdapat perbedaan tidak bermakna. Hasil Uji Tukey menunjukkan bahwa adanya perbedaan bermakna antara $\mathrm{K} 2$ dengan $\mathrm{K} 3, \mathrm{~K} 4, \mathrm{~K} 5$ dan K6 karena memiliki nilai sig. $<0.05$.

\section{Gambaran Histologi Hati Tikus Putih}

Gambaran histologi hati tikus putih (Gambar 2) terlihat gambaran histopatologi hepatosit yang normal pada K1 (kontrol negatif), sedangkan pada K2 kelompok hiperlipidemia (kontrol positif) terlihat adanya nekrosis yang ditandai dengan tidak adanya inti di hepatosit (kariolisis). Pada K3 menunjukan gambaran normal tetapi pada K3(2) terdapat sel Kupffer. Pada K4 dan K5 menunjukan gambaran sel normal. Tetapi pada K4(4) terdapat sel Kupffer (Gambar 2).
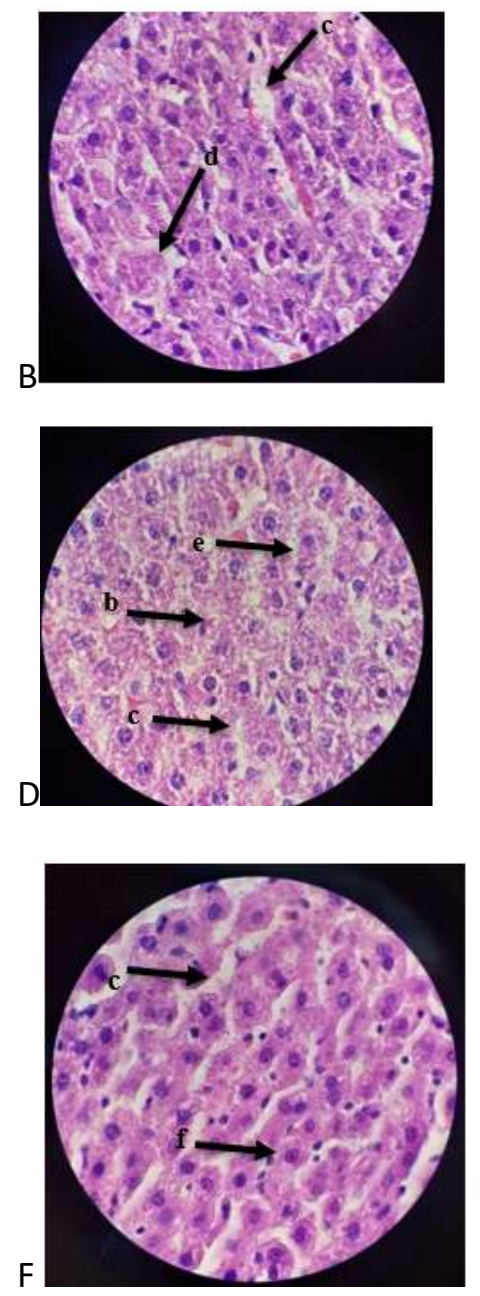


\section{Pembahasan}

Pada penelitian ini terdapat pengaruh pemberian ekstrak biji ketumbar (Coriandrum sativum) terhadap kadar trigliserida tikus putih (Rattus norvegicus) yang diinduksi hiperlipidemia. Perubahan kadar trigliserida tikus tersebut disebabkan karena ekstrak biji ketumbar memiliki aktivitas antioksidan yang dapat menurunkan kadar trigliserida tikus putih dan memiliki kandungan alkaloid yang berperan sebagai inhibitor enzim lipase sehingga meningkatkan sekresi lemak melalui feses serta mengurangi deposit trigliserida yang masuk dari usus halus ${ }^{17}$.

Sebuah penelitian tentang ekstrak biji ketumbar menunjukkan adanya aktivitas antioksidan terhadap 1,1-diphenyl-2picrylhydrazyl (DPPH) dan uji $\beta$-karoten, karena semakin tinggi persentase linalool, dan persentase $\alpha$-pinene yang luar biasa, $\beta$-pinene, $p$ cymene dan l-terpinene yang berperan pada aktivitas antioksidan dari rempah-rempah ${ }^{12}$, aktivitas antioksidan ini dapat mengurangi kadar LDL dan very low density lipoprotein (VLDL) yang terdiri dari $85-90 \%$ lipid (55\% trigliserida, $20 \%$ kolesterol, $15 \%$ fosfolipid) dan 10-15\% protein. Antioksidan dapat mencegah oksidasi LDL, memblokade ambilan LDL oleh makrofag, mencegah pembentukan foam cell, dan mencegah arteroklerosis ${ }^{18}$.

Adanya perbedaan kadar trigliserida diantara $\mathrm{K} 2$ dengan $\mathrm{K} 3, \mathrm{~K} 4$, K5, dan K6 diduga terjadi karena adanya kandungan ekstrak biji ketumbar yang dapat menurunkan kadar trigliserida pada tikus putih, yang salah satu kandungannya yaitu alkaloid yang bekerja sebagai antioksidan. Senyawa tersebut juga dapat menghambat aktivitas enzim lipase pankreas sehingga meningkatkan sekresi lemak melalui feses, akibatnya penyerapan lemak oleh hati terhambat sehingga tidak dapat diubah menjadi kolesterol. Berkurangnya aktivitas enzim lipase pankreas dapat mengurangi deposit trigliserida yang masuk dari usus halus karena enzim tersebut mengubah trigliserida menjadi dua monogliserid dan dua asam lemak bebas sehingga dapat masuk ke pembuluh darah ${ }^{17}$.

Pada hasil pengamatan histologi yang telah dilakukan terdapat perbedaan mikroanatomi hati pada kelompok perlakuan yang tidak diberi ekstrak biji ketumbar (K2). K2 mengalami kariolosis pada gambaran mikroanatomi hati, hal tersebut dapat diakibatkan oleh tingginya paparan lemak yang terdapat dalam pakan tikus tersebut. Kerusakan mikroanatomi hati secara langsung ternyata berkaitan dengan struktur makroskopis hati, ditandai dengan adanya hati yang berwarna merah pucat dan bertekstur licin, berbintikbintik kemerah-merahan. Struktur mikroanatomi hati dan makroanatomi hati yang berubah/tidak normal dicurigai diakibatkan oleh adanya asam lemak tidak jenuh yang mengandung senyawa eikosanoid yang berpotensi toksik. Dalam keadaan tersebut kerusakan sel diduga disebabkan oleh senyawa toksik eukasonoid yang diperkirakan terbentuk paska pemberian pakan tinggi lemak ${ }^{19}$ tanpa disertai pemberian ekstrak biji ketumbar terhadap kelompok tersebut (K2). Ekstrak biji ketumbar mengandung beberapa senyawa seperti riboflavin, niasin dan flavonoid yang dapat mendegradasi lemak jenuh dan toksik. Selain itu, zat aktif flavonoid sebagai antioksidan pada eksrak biji ketumbar mampu menurunkan stress oksidatif sehingga mengurangi reactive oxygen spesies (ROS) yang dapat menyebabkan kerusakan hati atau sirosis hati. Adanya perbedaan pada mikroanatomi hati tikus putih yang diberikan ekstrak biji ketumbar salah satunya diakibatkan oleh daya antioksidan dan hepatoprotektif. Antioksidan yang cukup akan membantu mencegah terjadinya kerusakan pada hati. Penambahan antioksidan juga diperlukan untuk mencegah atau meredam kerusakan dari oksidatif. Tikus yang mendapat diet serbuk biji ketumbar menunjukkan peningkatan aktivitas enzim antioksidan yang signifikan seperti superoxide dismutase (SOD), katalase, glutation peroksidase (GPx), glutation transferase, glukosa 6 fosfat dehidrogenase dan glutation reduktase pada hati tikus yang diuji ${ }^{20}$, hal inilah yang menyebabkan penampakan mikroanatomi hati pada K2 mengalami nekrosis dan kariolisis.

Kerusakan sel dapat diakibatkan oleh proses fisika, kimiawi maupun mikroorganisme, hal ini dapat bersifat sementara ataupun berakhir dengan kematian sel. Nekrosis merupakan perubahan morfologi yang diakibatkan oleh degradasi progresif enzim - enzim pada sel. Nekrosis juga merupakan proses kematian sel yang terjadi akibat kerusakan sel dan ditandai 
dengan adanya pembengkakan serta kerusakan pada organel sel. Inti sel yang mati akan menyusut (piknotik) dan memadat, dengan batas yang tidak teratur dan berwarna gelap ${ }^{21}$. Selanjutnya inti sel hancur dan meninggalkan pecahan-pecahan zat kromatin yang tersebar di dalam sel yang disebut karioreksis sedangkan inti menghilang dan disebut kariolisis. Proses penting yang menunjukkan perubahan nekrosis adalah pencernaan sel enzim dan denaturasi protein. Inti pada sel nekrosis sama sekali menghilang dalam satu sampai dua hari. Sitoplasma berubah menjadi masa asidofil gelap bergranula. Asidofil mencerminkan afinitas terhadap zat warna asam (eosinofil) yang sebagian terjadi akibat dari denaturasi protein sitoplasma. Selanjutnya sel nekrosis berubah menjadi bangkai asidofil tanpa inti ${ }^{21}$.

\section{Kesimpulan}

Ekstrak biji ketumbar berpengaruh terhadap penurunan kadar trigliserida serum darah tikus dan adanya perubahan histologi hati pada kelompok tikus yang diberikan ekstrak biji ketumbar (Coriandrum sativum) dibandingkan dengan kelompok yang tidak diterapi.

\section{Saran}

Penelitian ini hanya menguji ekstrak kasar biji ketumbar, sehingga diperlukan uji lebih lanjut mengenai senyawa aktif yang terkandung dalam biji ketumbar yang berperan sebagai anti hipertrigliseridemia dan perlu dilakukan teknik pewarnaan imunohistokimia untuk mengamati protein yang terdapat dalam sediaan histologi hati tikus.

\section{Ucapan Terima Kasih}

Penulis mengucapkan terimakasih kepada Irma Mulyani, S.ST., M.Tr. Keb selaku Kepala Laboratorium Sekolah Tinggi Ilmu Kesehatan Rajawali, atas izin untuk melakukan penelitian. Ucapan terimakasih juga kami sampaikan kepada Aziz Ansori Wahid, S.ST., M.Si, selaku rekan penelitian sekaligus Ketua Program Studi DIII Analis Kesehatan Sekolah Tinggi Ilmu Kesehatan Rajawali dan Tonika Tohri, S.Kp., M.Kes selaku Ketua Sekolah Tinggi Ilmu Kesehatan Rajawali atas pendanaan penelitian.

\section{Daftar Pustaka}

1. Nouh F, Omar M, Younis M. Risk Factors and
Management of Hyperlipidemia. Asian $J$ Cardiol Res. 2019;2(1):1-10. doi:10.9734/AJCR/2019/45449

2. R S, S N. A Mini-Review on Hyperlipidemia: Common Clinical Problem. Interv Cardiol J. 2018;04(03):10-12. doi:10.21767/24718157.100080

3. Syafitri V, Arnelis A, Efrida E. Gambaran Profil Lipid Pasien Perlemakan Hati Non-Alkoholik. $J$ Kesehat Andalas. 2015;4(1):274-278. doi:10.25077/jka.v4i1.234

4. Rosida A. Pemeriksaan Laboratorium Penyakit Hati. Berk Kedokt. 2016;12(1):123. doi:10.20527/jbk.v12i1.364

5. Gitawati R, Widowati L, Suharyanto Pusat Teknologi Terapan Kesehatan dan Epidemiologi Klinik F, Penelitian dan Pengembangan Kesehatan B, Kesehatan K. Penggunaan Jamu pada Pasien Hiperlipidemia Berdasarkan Data Rekam Medik, di Beberapa Fasilitas Pelayanan Kesehatan di Indonesia The Use of Jamu in Patients with Hyperlipidemia Based on Data from the Medical Record, in Some Health Care Facilities, in Indon. $J$ Kefarmasian Indones. 2015;5(1):41-48.

6. Hasanah N, Dori RS. Daya Hambat Ekstrak Biji Ketumbar (Coriandrum sativum L.) terhadap Pertumbuhan Bakteri Shigella dysenteriae Metode Cakram. Edu Masda J. 2019;3(2):115122.

7. FG CE, JW S. In Vitro Carbohydrate Digestibility of Copper Nanoparticulated Bitter Gourd Extract. J Nutr Food Sci. 2016;06(02):25. doi:10.4172/2155-9600.1000482

8. Hardiningtyas SD, Purwaningsih S-, Handharyani E-. Aktivitas Antioksidan Dan Efek Hepatoprotektif Daun Bakau Api-Api Putih. $J$ Pengolah Has Perikan Indones. 2014;17(1):80-91. doi:10.17844/jphpi.v17i1.8140

9. Güler T, Ertaş ON, Çiftçi M, Dalkihç B. The effect of coriander seed (Coriandrum sativum L.) as diet ingredient on the performance of Japanese quail. South African J Anim Sci. 2005;35(4):261-267.

doi:10.4314/sajas.v35i4.3969

10. Willy dr. T. Simvastatin. alodokter.com.

11. Hasanah A. Efek Jus Bawang Bombay (Allium Cepa Linn.) Terhadap Motilitas Spermatozoa Mencit Yang Diinduksi Streptozotocin (Stz). Saintika Med. 2017;11(2):92. doi:10.22219/sm.v11i2.4203

12. Astuti P, Rosyana E. Ekstraksi Minyak Ketumbar (Coriander Oil) Dengan Pelarut Etanol Dan N-Heksana. $J$ Bahan Alam Terbarukan. 2013;1(1):1-1. 
13. Agustina W, Nurhamidah dan DH. Skrining Fitokimia Dan Aktivitas Antioksidan Beberapa Fraksi Dari Kulit Bantang Jarak (Ricinus communis L.). $J$ Pendidik dan Ilmu Kim. 2017;1(2):Hlm. 117-122.

14. Direktorat Jenderal, Pengawasan Obat dan Makanan DKR, Indonesia. Pedoman Pengujian Dan Pengembangan Fitofarmaka: Penapisan Farmakologi, Pengujian Fitokimia, Dan Pengujian Klinik. Jakarta: Direktorat Jenderal Pengawasan Obat dan Makanan, Departemen Kesehatan Republik Indonesia; 1993.

15. Hardisari R, Koiriyah B. Gambaran Kadar Trigliserida (Metode Gpo-Pap) Pada Sampel Serum dan Plasma EDTA. J Teknol Lab. 2016;5:27-31.

16. Durachim A, Mahmud D. Sitohistoteknologi. Bandung: Poiteknik Kesehatan Bandung; 2017.

17. Artha C, Mustika A, Sulistyawati SW. Pengaruh Ekstrak Daun Singawalang Terhadap Kadar LDL Tikus Putih Jantan Hiperkolesterolemia. eJournal Kedokt Indones. 2017. doi:10.23886/ejki.5.7151.

18. Kurniawati A, Putri E. Uji Efek Antihiperlipidemia Ekstrak Etanol Buah Parijoto (Medinilla Speciosa Blume) Terhadap Kolesterol Total, Trigliserida, Dan VLDL Pada Tikus Putih Jantan. 2015.

19. Surasa NJ, Utami NR, Isnaeni W. Struktur Mikroanatomi Hati dan Kadar Kolesterol Total Plasma Darah Tikus Putih Strain Wistar Pasca Suplementasi Minyak Lemuru dan Minyak Sawit. Biosaintifika $J$ Biol Biol Educ. 2014;6(2):117-127. doi:10.15294/biosaintifika.v6i2.3778

20. Handayani SR. . Aktivitas Antihiperglikemia,Penghambatan Stres Oksidatif Dan Regenerasi Pankreas Ekstrak Biji Ketumbar (Coriandrum Sativum L.) Pada Tikus Yang Diinduksi Aloksan. 2015.

21. Cut Sriyanti. Patologi. 1st ed. (Suyanto, ed.). Kementerian Keehatan Republik Indonesia; 2016. 